\title{
Freshwater crabs could act as vehicles of spreading avian influenza virus
}

\author{
Weiwei Ma, Chenyang Ren, Qingbiao Hu, Xiaodong Li, Yali Feng and Ying Zhang* (1)
}

\begin{abstract}
Avian influenza virus (AIV) possessed significant risk to various animals and human health. Wild birds, especially waterfowls are considered to be the natural reservoir of AIVs. The ecology of AIV is still far from being fully understood. Freshwater crabs are nonnegligible biotic factor in AIV ecosystem. We analyzed the ability of freshwater crabs accumulate and spread AIV. We found that AIV remain infectious in water only for $36 \mathrm{~h}$ but persist in crabs for $48 \mathrm{~h}$. Crabs could accumulate AIV in their gills and gastrointestinal tracts. The AIV titers in crabs were higher than the surrounding contaminated water. Crabs could accumulate AIV from contaminated water, carry the virus and spread to naïve crabs via surrounding water. Our study identified freshwater crab as a novel transmission vehicle in AlV ecosystem.
\end{abstract}

Keywords: Avian influenza virus, Freshwater crab, Aquatic, Spread

\section{Introduction}

Avian Influenza virus (AIV) is important pathogen for both human and animals. AIV is a RNA virus composed of 8 genome segments. Hemagglutinin (HA) and neuraminidase (NA) are two major glycoproteins on the surface of AIV. AIV can be classified into 18 HA (H1H18) and 11 NA (N1-N11) subtypes based on the different antigenicity of HA and NA. All of these subtypes have been found in wild birds excepting for H17N10 and H18N11 subtypes [1, 2]. So it has been widely accepted that wild birds, especially waterfowls are the natural reservoir of AIVs. Occasionally, AIV in waterfowls could spill over to domestic poultry, livestock, marine mammals and even humans $[3,4]$.

AIVs mainly replicate in the intestine tract cells of waterfowls [5], so the infected bird faeces may contain high concentration of AIVs. The faecal-oral route is considered to be the primary AIV transmission mode in

${ }^{*}$ Correspondence: yingzhang18@syau.edu.cn

Key Laboratory of Livestock Infectious Diseases, Ministry of Education, Key Laboratory of Zoonosis, College of Animal Science and Veterinary Medicine, Liaoning Panjin Wetland Ecosystem National Observation and Research Station, Shenyang Agricultural University, 120 Dongling Rd, Shenyang 110866, People's Republic of China waterfowls. It has been reported that AIVs can remain infectious in aquatic environment for more than seven months [6]. As a result, it makes the aquatic environment become an epidemic focus where AIV could transmit among waterfowl and other animal living in the same area [7].

Freshwater crabs are widely existing in freshwater lakes, rivers and brackish waters [8]. It is an omnivorous animal which mainly feed on plant and animal detritus [9]. In the wild, the crabs could also be the prey of waterfowl and poultry. Sharing same aquatic habitats and being in predation relation with waterfowls, freshwater crabs might become a transmission biotic factor in AIV ecosystem. Chinese mitten crab (Eriocheir sinensis) is the main freshwater crab species in China. It belongs to Malacostraca, Decapoda, Grapsidae. In this study we used Chinese mitten crabs as a representative model to evaluate the function of freshwater crab in AIV ecosystem.

\section{Materials and methods}

\section{Freshwater crabs}

The Chinese mitten crabs used in this experiment weighed $10.0 \pm 1.0 \mathrm{~g}$ were kindly provided by Panjin Guanghe Crab industry Co Ltd. The crabs were kept in aerated water for 2 weeks at $18^{\circ} \mathrm{C}$. 
Aerated water was made by pumping air into 20 Liter tap water with an air pump $(20 \mathrm{~L} / \mathrm{min})$ overnight. Finally, the dissolved oxygen and $\mathrm{pH}$ level of the aerated water was $6.4 \mathrm{mg} / \mathrm{mL}$ and 7.2 respectively.

\section{Virus and cell}

H9N2 avian influenza virus A/chicken/Liaoning/07/2016 was isolated from chicken during routine surveillance. Virus stock was propagated in Madin-Darby canine kidney (MDCK) cells and stored at $-80{ }^{\circ} \mathrm{C}$. The viral titer was determined by $50 \%$ tissue culture infectious dose $\left(\mathrm{TCID}_{50}\right)$.

Persistence of Avian influenza virus in the aerated water The viral water was made by adding $10^{7.5}$ TCID $_{50}$ of AIV into 1 Liter aerated water, mixing thoroughly. Three tanks with $1 \mathrm{~L}$ viral water were put into a biosafety cabinet at $18{ }^{\circ} \mathrm{C}$. $1 \mathrm{ml}$ water sample was taken from each tank after $0,1,3,8,12,24,36,48$ and 60 hours (h) respectively to test the viral titer in MDCK cells.

\section{AIV accumulation in freshwater crabs}

Five groups crabs (3 per group) were distributed into five viral water tanks. At $0,1,3,8$ and $12 \mathrm{~h}$ post incubation (hpi), one group of three crabs were rinsed and euthanized. Crabs gills, hepatopanpancreas, gastrointestinals, muscles and viral water sample were collected for viral titration.

\section{AIV accumulating limitation of crabs}

Six groups of crabs (3 per group) were incubated in viral water. Every $12 \mathrm{~h}$, the tank water was changed with fresh viral water until $60 \mathrm{~h}$ later. Since $0 \mathrm{~h}$ after incubation, one group of crabs were rinsed and euthanized for gills collection before water changing. The viral water sample was collected at the same time.

\section{AIV spreading activity of freshwater crabs}

Groups of 3 crabs were incubated in viral water for $8 \mathrm{~h}$ as inoculated groups. After rinsing thoroughly, the inoculated crabs were transferred into fresh water. Groups of 3 naïve crabs, as sentinel groups, were put into each tank and co-cultured with inoculated groups. The inoculated and sentinel groups crabs' samples were collected immediately after co-cultured. During the first $4 \mathrm{~h}$ post co-cultured (hpc), every $0.5 \mathrm{~h} 1$ group of inoculated and sentinel crabs were rinsed and euthanized. Their gills and water sample were collected at the same time for viral titration. The crabs and water samples were also collected at $8,12,24,36,48$ and $60 \mathrm{hpc}$ respectively.

\section{Results}

Infectivity changes of AIV in lab water tank over time

As shown in Fig. 1, AIV could maintain similar infectivity for $3 \mathrm{~h}$. Viral titer began to drop at $8 \mathrm{hpi}$. At $24 \mathrm{hpi}$, viral titer dropped by half. There's no detectable virus in water after $36 \mathrm{~h}$.

\section{Freshwater crabs could accumulate AIV from surrounding water}

Groups of 3 crabs were inoculated by incubating in viral water. As shown in Table 1, AIV could be detected in crabs' gills and intestinal tracts since 1 hpi. The crabs' gills accumulated AIV more efficiently than their gastrointestinal tracts. After $8 \mathrm{~h}$ of virus inoculation, the virus titer in crab gills was higher than that in water. At $36 \mathrm{hpi}$, the viral titers in crabs began to drop. Whereas, viral titer in water kept on dropping from the beginning of the experiment. AIV could still be detected in 1 crab's gill at $36 \mathrm{hpi}$ and in 1 crab's gill and gastrointestinal tract at 48 hpi. No virus was detected in other organs of the crabs. It explained that AIV could "infect" crabs through their respiratory and digestive systems. There's no detectable AIV after $48 \mathrm{hpi}$ in neither crabs nor in water.

\section{Freshwater crabs could accumulate AIV virus constantly}

The crabs surrounding viral water was refreshed every $12 \mathrm{~h}$. The viral titers in crabs were consistent but higher than viral water (As shown in Fig. 2). So the Chinese mitten crabs could continue accumulating AIV but might be confined by their size or viral titer in water.

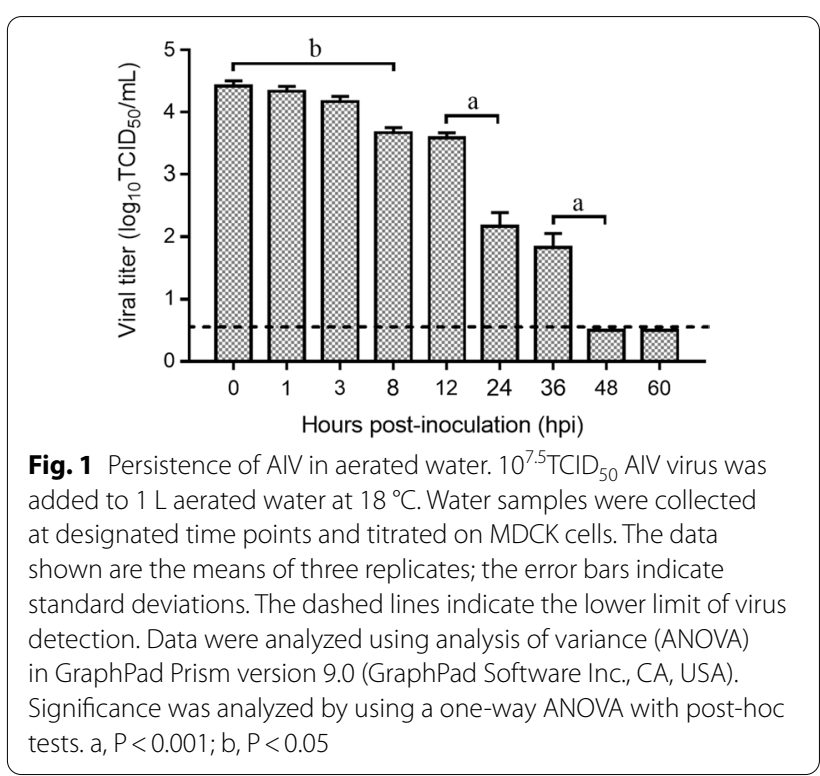


Table 1 AlV accumulation in freshwater crabs

\begin{tabular}{|c|c|c|c|c|c|}
\hline \multirow{2}{*}{$\begin{array}{l}\text { Hours post inoculation } \\
\text { (hpi) }\end{array}$} & \multicolumn{5}{|c|}{ Viral titer $\left(\log _{10} \mathrm{TCID}_{50} / \mathrm{mL}\right)^{\mathrm{a}}$} \\
\hline & Gill & Gastrointestinal tract & Hepatopancreas & Muscle & Water \\
\hline 0 & - & - & - & - & 4.25 \\
\hline 1 & $2.62 / 2.02 / 2.01$ & $2.82 / 2.62 /-$ & - & - & 3.75 \\
\hline 3 & $3.14 / 3.07 / 2.83$ & $3.11 /-/-$ & - & - & 3.50 \\
\hline 8 & $4.96 / 4.91 / 4.61$ & $2.92 /-/-$ & - & - & 2.75 \\
\hline 12 & $4.88 / 4.45 / 4.18$ & $2.18 /-/-$ & - & - & 3.25 \\
\hline 24 & 4.97/3.94/- & - & - & - & 2.50 \\
\hline 36 & $2.68 /-/-$ & - & - & - & 2.25 \\
\hline 48 & $2.70 /-/-$ & $2.62 /-/-$ & - & - & 1.50 \\
\hline 60 & - & - & - & - & - \\
\hline
\end{tabular}

${ }^{a}$ Five groups crabs ( 3 per group) were distributed into 5 viral water tanks. After $0,1,3,8$ and $12 \mathrm{~h}$ incubation, 1 group of 3 crabs were rinsed and euthanized. Crabs gills, gastrointestinal tract, hepatopancreas, muscle tissue and viral water were collected for viral titration in MDCK cells

- , no virus was detected in samples

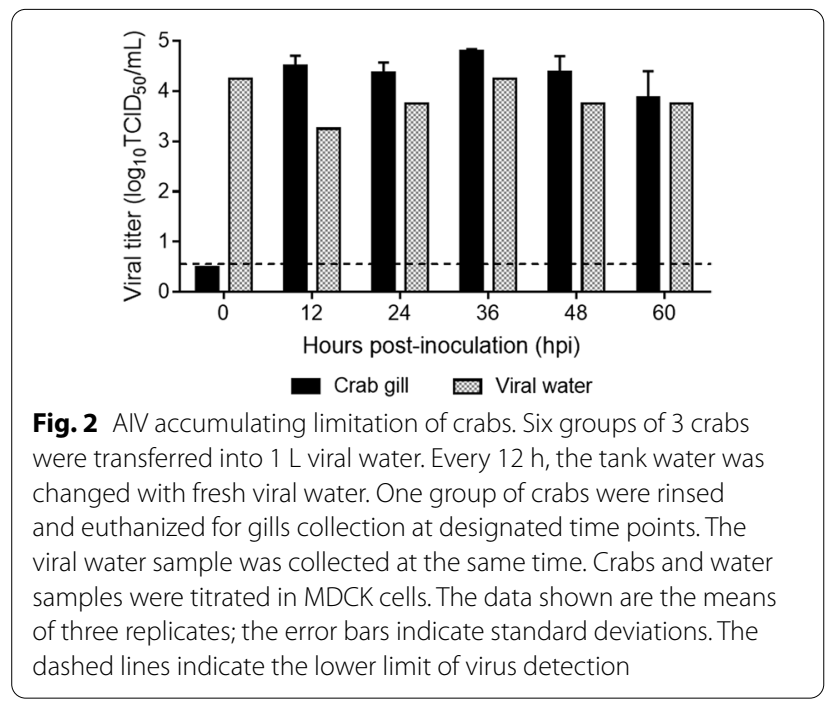

\section{Freshwater crabs spread AIV to surrounding water and naïve crabs}

We inoculated crabs by incubating them in viral water for $8 \mathrm{~h}$ and used them as the inoculated groups. Groups of 3 naïve crabs were treated as sentinel groups. As shown in Table 2, AIV could be detected from inoculated crabs until 8 hpi. Since 1 hpi, AIV was detected from 2 of the 3 sentinel crabs. At $2.5 \mathrm{hpi}$, AIV was only detected from 1 sentinel crab. There's no detectable AIV in sentinel groups after $3 \mathrm{hpi}$. AIV was detected from water at 1 and $1.5 \mathrm{hpi}$. However, there was no live virus in the water after two hours. The inoculated groups contained higher viral titer than sentinel groups and water. The result indicated that, AIV contaminated crabs could spread virus into water and "infect" the naïve crabs.
Table 2 AIV spreading activity of freshwater crabs

\begin{tabular}{llll}
\hline $\begin{array}{l}\text { Hours post } \\
\text { co-cultured }(\mathrm{hpc})\end{array}$ & \multicolumn{2}{l}{ Viral titer $\left(\log _{10} \mathbf{T C I D}_{\mathbf{5 0}} / \mathrm{mL}\right)^{\mathbf{a}}$} \\
\cline { 2 - 4 } & Inoculated crabs & Sentinel crabs & Water \\
\hline 0 & $4.96 / 4.91 / 4.61$ & - & - \\
0.5 & $4.05 / 3.71 / 3.67$ & - & - \\
1 & $3.74 / 3.62 / 3.18$ & $2.89 / 2.34 /-$ & 2.50 \\
1.5 & $3.84 / 2.85 / 2.35$ & $2.95 / 2.45 /-$ & 2.25 \\
2 & $3.68 / 3.17 / 2.13$ & $2.60 / 2.35 /-$ & - \\
2.5 & $3.24 / 2.68 / 2.16$ & $2.68 /-/-$ & - \\
3 & $2.49 / 2.32 /-$ & - & - \\
3.5 & $2.70 /-/-$ & - & - \\
4 & $2.57 /-/-$ & - & - \\
8 & $2.49 /-/-$ & - & - \\
12 to $60^{*}$ & - & - & - \\
\hline
\end{tabular}

${ }^{a}$ Groups of 3 crabs were inoculated by incubating in viral water for $8 \mathrm{~h}$. After rinsing thoroughly, the inoculated crabs were transferred into fresh water tanks. Groups of 3 sentinel crabs were put into each tank. At designated time points, 1 group of inoculated and sentinel crabs were rinsed and euthanized. Their gills and water were collected at the same time for viral titration in MDCK cells.

- , no virus was detected in samples

*Crabs and water samples were collected every $12 \mathrm{~h}$

\section{Discussion}

Pathogenic ecology of AIV including host, pathogen and environment. The biotic and abiotic factors of environment play important roles in AIV spreading process. Waterfowls especially the migratory waterfowls can disseminate AIV along their flyways. There's high possibility that freshwater crabs could be contaminated by AIV shedding from the waterfowls.

Crabs could be good indicators reflecting the contaminating levels in their living environments. Crabs resided in the surfical sediment and might feed on contaminated sediments, so the aquatic contaminants surveillance 
conducting on crab could be more sensitive than on fish and water. It could be used as indicators for contaminants such as heavy metals, polychlorinated dibenzo-p-dioxins and dioxin-like (dl) PCBs [10, 11]. Researchers found AIV RNA in small aquatic vertebrates and invertebrates, such as water fleas [12], bamboo shrimp (Atyopsis moluccensis), clams (Corbicula fluminea), freshwater snails (Physa spp.), zebra mussels (Dreissena ploymorpha), crayfish and Mediterranean cone shell (Conus sp.). Experiments indicated these aquatic animals can accumulate AIVs through water filtering but the infectivity of these accumulated AIV had not been evaluated yet [13-18]. Our study for the first time evaluated the infectivity of accumulated AIV in crabs and determined the AIV spreading activity of freshwater crabs. The results indicated that freshwater crab could also act as an AIV indicator in aquatic environment. Viral contaminating levels in crabs might be included in the future AIV field surveillance activities.

Further study should be conducted to evaluate the AIV transmission between freshwater crabs and their predators.

\section{Conclusion}

In the present study, we evaluated the accumulation and spreading of AIV in freshwater crabs. AIV could be accumulated in multiple organs of the crabs and stay infectious longer than in water. Most importantly, AIV could be carried by the crabs into freshwater and transmitted to the naïve crabs. Our study indicates that freshwater crabs are important factors in the AIV ecosystem.

\section{Abbreviations \\ AIV: Avian influenza virus; HA: Hemagglutinin; NA: Neuraminidase; MDCK: Madin-Darby canine kidney; $\operatorname{TCID}_{50}: 50 \%$ Tissue culture infectious dose; $\mathrm{h}$ : Hours; hpi: Hours post inoculation; hpc: Hours post co-cultured.}

\section{Acknowledgements}

Not applicable.

\section{Authors' contributions}

Y.Z. designed the experiment. W.M., C.R., Q.H., Y.F., conducted the experiments. W.M., Q.H., X.L. and Y.Z. analyzed the data. W.M. and Y.Z. wrote the manuscript. All authors read and approved the final manuscript.

\section{Funding}

This work was supported by the National Key Research Project (2021YFD1800042), National Natural Science Foundation of China (32170539, 32000357), Liao Ning Revitalization Talents Program (XLYC2007114), Key Research and Development Program of Liaoning (2020JH2/10200035).

\section{Availability of data and materials}

All data generated or analysed during this study are included in this published article.

\section{Declarations}

Ethics approval and consent to participate

The animal research was approved by the Committee on the Ethics of Animal Experiments of Key Laboratory of Livestock Infectious Diseases in Northeast China, Ministry of Education.
Consent for publication

All authors consent to the publication of the manuscript.

\section{Competing interests}

The authors declare that they have no competing interests.

Received: 22 October 2021 Accepted: 21 November 2021

Published online: 11 December 2021

References

1. Tong S, Li Y, Rivailler P, Conrardy C, Castillo DA, Chen LM, et al. A distinct lineage of influenza A virus from bats. Proc Natl Acad Sci USA 2012;109(11):4269-74. https://doi.org/10.1073/pnas.1116200109.

2. Tong S, Zhu X, Li Y, Shi M, Zhang J, Bourgeois M, et al. New world bats harbor diverse influenza A viruses. PLoS Pathog. 2013;9(10): e1003657. https://doi.org/10.1371/journal.ppat.1003657.

3. Li Y, Shi J, Zhong G, Deng G, Tian G, Ge J, et al. Continued evolution of H5N1 influenza viruses in wild birds, domestic poultry, and humans in China from 2004 to 2009. J Virol. 2010;84(17):8389-97. https://doi.org/10. 1128/JVI.00413-10.

4. Chen H, Li Y, Li Z, Shi J, Shinya K, Deng G, et al. Properties and dissemination of $\mathrm{H} 5 \mathrm{~N} 1$ viruses isolated during an influenza outbreak in migratory waterfowl in western China. J Virol. 2006;80(12):5976-83. https://doi.org/ 10.1128/JVI.00110-06.

5. Webster RG, Yakhno M, Hinshaw VS, Bean WJ, Murti KG. Intestinal influenza: replication and characterization of influenza viruses in ducks. Virology. 1978;84(2):268-78. https://doi.org/10.1016/0042-6822(78)90247-7.

6. Ramey AM, Reeves AB, Drexler JZ, Ackerman JT, De La Cruz S, Lang AS, et al. Influenza A viruses remain infectious for more than seven months in northern wetlands of North America. Proc Biol Sci. 1934;2020(287):20201680. https://doi.org/10.1098/rspb.2020.1680.

7. Ito T, Okazaki K, Kawaoka Y, Takada A, Webster RG, Kida H. Perpetuation of influenza A viruses in Alaskan waterfowl reservoirs. Arch Virol. 1995;140(7):1163-72. https://doi.org/10.1007/BF01322743.

8. Zhang D, Qi T, Liu J, Liu Q, Jiang S, Zhang H, et al. Adaptively differential expression analysis in gill of Chinese mitten crabs (Eriocheir japonica sinensis) associated with salinity changes. Int J Biol Macromol. 2018;120(Pt B):2242-6. https://doi.org/10.1016/j.ijbiomac.2018.08.054

9. Zhang L, Zhu C, Yang J, Song W, Jiang Z. Environmental investigation of crab breeding farm in Yangtze River Estuary. Fish Sci Technol Inform. 1988;01:3-13 (in Chinese).

10. Hoogenboom RL, Kotterman MJ, Hoek-van Nieuwenhuizen M, van der Lee MK, Mennes WC, Jeurissen SM, et al. Dioxins, PCBs and heavy metals in Chinese mitten crabs from Dutch rivers and lakes. Chemosphere. 2015;123:1-8. https://doi.org/10.1016/j.chemosphere.2014.10.055.

11. Zhao S, Feng C, Quan W, Chen X, Niu J, Shen Z. Role of living environments in the accumulation characteristics of heavy metals in fishes and crabs in the Yangtze River Estuary. China Marine Pollut Bull. 2012;64(6):1163-71. https://doi.org/10.1016/j.marpolbul.2012.03.023.

12. Abbas MD, Nazir J, Stumpf P, Marschang RE. Role of water fleas (Daphnia magna) in the accumulation of avian influenza viruses from the surrounding water. Intervirology. 2012;55(5):365-71. https://doi.org/10.1159/ 000334691

13. Pathak AP, Murugkar HV, Nagarajan S, Sood R, Tosh C, Kumar M, et al. Survivability of low pathogenic (H9N2) avian influenza virus in water in the presence of Atyopsis moluccensis (Bamboo shrimp). Zoonoses Public Health. 2018;65(1):e124-9. https://doi.org/10.1111/zph.12420.

14. Faust C, Stallknecht D, Swayne D, Brown J. Filter-feeding bivalves can remove avian influenza viruses from water and reduce infectivity. Proc Biol Sci. 2009;276(1673):3727-35. https://doi.org/10.1098/rspb.2009.0572.

15. Huyvaert KP, Carlson JS, Bentler KT, Cobble KR, Nolte DL, Franklin AB. Freshwater clams as bioconcentrators of avian influenza virus in water. Vector Borne Zoonotic Dis (Larchmont, NY). 2012;12(10):904-6. https:// doi.org/10.1089/vbz.2012.0993.

16. Oesterle PT, Huyvaert KP, Orahood D, Mooers N, Sullivan H, Franklin AB, et al. Failure of transmission of low-pathogenic avian influenza virus between Mallards and freshwater snails: an experimental evaluation. J Wildl Dis. 2013;49(4):911-9. https://doi.org/10.7589/2012-04-111. 
17. Stumpf P, Failing K, Papp T, Nazir J, Böhm R, Marschang RE. Accumulation of a low pathogenic avian influenza virus in zebra mussels (Dreissena polymorpha). Avian Dis. 2010;54(4):1183-90. https://doi.org/10.1637/ 9162-111709-Reg.1.

18. Root JJ, Ellis JW, Shriner SA. Effects of freshwater crayfish on influenza A virus persistence in water. Zoonoses Public Health. 2020;67(3):300-7. https://doi.org/10.1111/zph.12688.

\section{Publisher's Note}

Springer Nature remains neutral with regard to jurisdictional claims in published maps and institutional affiliations.

- fast, convenient online submission

- thorough peer review by experienced researchers in your field

- rapid publication on acceptance

- support for research data, including large and complex data types

- gold Open Access which fosters wider collaboration and increased citations

- maximum visibility for your research: over 100M website views per year

At BMC, research is always in progress.

Learn more biomedcentral.com/submissions 